\title{
한국의 아프리카 개발협력 현황과 전략 제안 ${ }^{1)}$
}

한 승 헌 KOICA 동아프리카팀 상임연구원

\begin{tabular}{|c|}
\hline 목차 \\
\hline I. 서언 \\
\hline II. 국제사회의 아프리카 지원 현황 \\
\hline III. 한국의 對아프리카 지원 현황 \\
\hline IV. 무상원조의 對아프리카 지원전략 제안 \\
\hline V. 결어 \\
\hline
\end{tabular}

\section{I. 서 언}

한국은 2006년 아프리카 이니셔티브 발표를 기점으로 대아프리카 ODA를 대폭 증액했고, 2009년 『제2차 한-아프리카 포럼 서울선언`과 함께 채택된 『한-아프리카 개발협력 기본구상 2009-2012』 를 토대로 대아프리카 지원의 기본 방향을 설정했다. 본 선언은 한국이 대아프리카 ODA를 2012년까 지 2008년 대비 2배 증액하고, 2009년 2012년간 아프리카인 연수생을 5천명까지 확대 초청하며, 아프리카 협력국에 대해 해외봉사단(“World Friends Korea”)을 1 천명 이상 확대 파견한다는 것을 주요 내용으로 담고 있다.

한국이 아프리카 지원을 확대하는 것은 최근 중국을 비롯한 많은 선진국들이 자원을 획득하기 위 해 대 아프리카 원조를 확대하는 조짐에 대한 반사작용이기도 할 것이나, 2010년 OECD/DAC 회원 국이 됨으로써 국제 사회의 빈곤 퇴치를 위한 노력에 동참하고자 하는 의지가 반영되었기 때문이라고 도 볼 수 있다. 실제로 국제사회는 2010년을 새천년개발목표(MDGs: Millenium Development Goals)의 달성을 위해 총력을 기울이는 기점으로 삼고, 각종 연구 보고서를 통해 MDGs 이행 현황을 분석하고, 2015년까지 목표를 달성하기 위한 대안을 제시하는 등 다각적인 노력을 기울이고 있다.

1) 이 글은 KOICA에서 발간한 「OECD/DAC 회원국의 대 아프리카 지원 전략과 시사점 (한승헌, 2010)」의 내용을 기초 로 하여 보완작성된 것임을 밝힌다. 
그러나 최근 아프리카 지원의 확대에도 불구하고, 한국의 아프리카 지원의 근거와 전략은 그 기반 이 취약하거나 구체성이 결여되어 있는 것이 사실이다. 즉, 현재 한국의 아프리카 지원 전략은 지금 까지 진행되어 왔던 사업 발굴에 따른 결과로 구성된 경향이 강하여, 아프리카 지역 및 국가들의 특 성과 우리의 비교우위를 반영한 지원 근거가 미미한 실정이다.

이는 그 동안 외교사 전체적인 맥락에서 한국이 4강 외교에 국한되어 있었던 이유도 있겠거니와, 지리적·문화적으로 근접한 아시아에 집중해왔던 원조 역사를 볼 때 아프리카는 한국에 있어 사회·문 화적으로 이질적인 지역이었기 때문이다. 특정 국가 혹은 지역의 지원 전략은 오랜 시간 동안 축적해 온 체계적인 이해와 정보가 뒷받침되어야만 수립될 수 있다. 따라서 이러한 결과는 지금까지 한국의 대 아프리카 외교 및 교역 등의 관계를 고려할 때 필연적이라 하겠다.

이러한 맥락에서, 본 글에서는 한국의 대 아프리카 원조 및 지원 현황을 간략히 살펴보고, 향후 몇 가지 한국의(정확히는 무상원조의) 아프리카 지원 전략을 제안하도록 하겠다.

\section{II. 국제사회의 아프리카 지원 현황}

2011년 아프리카 지역은(특히 사하라이남) 지속적인 성장에의 기회를 갖게 되었다. 2007년 후반 부터 글로벌 금융 위기가 시작되기 전까지, 각국마다 차이는 있지만 아프리카 지역은 매년 평균 $5 \%$ 의 경제성장을 달성해왔고, 특히 2006년 2008년에는 $6 \%$ 이상의 경제성장을 달성했다. 2007년 후 반부터 글로벌 금융 위기로 인해 전반적인 경제상황이 악화되기는 했으나, 2010년에는 아프리카 각 국들의 성공적인 거시경제 정책과 여러 공여국·기관들의 재정지원에 힘입어 아프리카의 경제는 회복 기에 접어들었다. 새천년개발목표(MDGs: Millennium Development Goals)는 말라위, 가나, 에티 오피아 등 몇몇 국가들에서 충분히 달성 가능한 양상을 보이고 있으며, 민간부문 역시 점차 투자자들 에게 매력적으로 변모하고 있다.

그러나 이러한 긍정적인 변화에도 불구하고, 아프리카 지역은 여전히 오랫동안 지속되어왔던 농업 중심의 단일한 생산구조, 열악한 인적자원, 허약한 정부, 국가적 취약함, 여성의 권익, 청년층의 고용 문제, 기후변화 등 다양한 발전에의 문제들에 직면해있다. 그리하여 지금까지 공여국·기관들은 아프 리카 지역에 약 $40 \%$ 의 재원을 집중함으로써 아프리카의 빈곤문제해결 및 지속가능한 경제성장을 도 모하기 위해 노력해왔다. 
〈표 1〉사하라이남 아프리카 지역의 평균 GDP 성장률, 1998-2008

(World Bank, 2011)

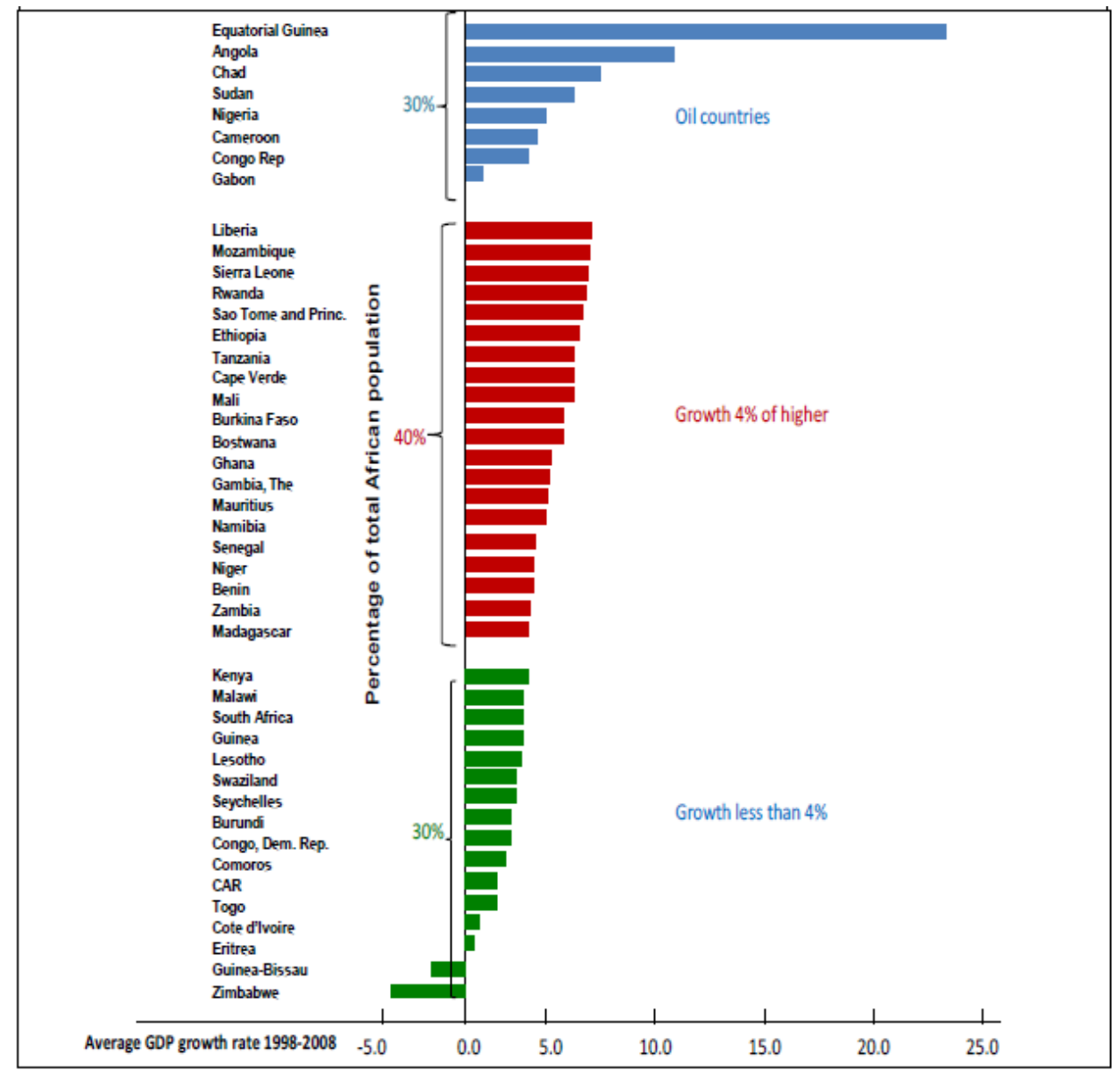

최근 국제사회의 아프리카 지원 현황을 보면, 2009년 아프리카 지역에 대한 지원(net disbursements 기준)은 전년대비 $11.7 \%$ 가 증가한 490 억 810 만 달러로, 이는 공여국 총 ODA(1,275억 2,700 만 달러) 의 약 37\%에 해당하는 규모이다. 2009년 ODA 10 대 수원국은 에티오피아, 탄자니아, 코트디부아르, 콩고민주공화국 등이며, 10 대 공여국· 기관은 미국, $\mathrm{EU}, \mathrm{IDA}$, 프랑스, 영국 등이다. ${ }^{2)}$

또한, 공여국·기관들이 지원한 분야별 현황은 사회분야가 $42 \%$ 로 지원율이 가장 높으며, 경제분야 는 $18 \%$, 일반적인 프로그램 원조가 $12 \%$, 생산분야가 $9 \%$ 등의 순이다. ${ }^{3)}$

2) OECD (2011)

3) $\mathrm{OECD} \mathrm{(2011).} \mathrm{인도적} \mathrm{지원} 8 \%$, 다양한 분야(multisector) $5 \%$, 부채탕감은 $4 \%$, 기타분야는 $1 \%$ 지원되었다. 
〈표 2〉ODA 10대 수원국 및 공여국·기관, 2009년

(USD million, net disbursement)

\begin{tabular}{c|c|c|c|c|c|c|c}
\hline \multicolumn{3}{c}{ 수원국 } & \multicolumn{4}{c}{ 공여국 및 기관 } \\
\hline 1 & 에티오피아 & 3,820 & $8 \%$ & 1 & 미국 & 7,672 & $16 \%$ \\
\hline 2 & 탄자니아 & 2,934 & $6 \%$ & 2 & EU & 5,606 & $12 \%$ \\
\hline 3 & 코트디부아르 & 2,366 & $5 \%$ & 3 & IDA & 4,823 & $10 \%$ \\
\hline 4 & 콩고민주공화국 & 2,354 & $5 \%$ & 4 & 프랑스 & 4,092 & $9 \%$ \\
\hline 5 & 수단 & 2,289 & $5 \%$ & 5 & 영국 & 2,795 & $6 \%$ \\
\hline 6 & 모잠비크 & 2,013 & $4 \%$ & 6 & AfDB & 2,582 & $5 \%$ \\
\hline 7 & 우간다 & 1,786 & $4 \%$ & 7 & 독일 & 2,084 & $4 \%$ \\
\hline 8 & 케냐 & 1,778 & $4 \%$ & 8 & IMF(SAF, ESAF, PRGF) & 2,076 & $4 \%$ \\
\hline 9 & 나이지리아 & 1,659 & $3 \%$ & 9 & 스페인 & 1,578 & $3 \%$ \\
\hline 10 & 가나 & 1,583 & $3 \%$ & 10 & 일본 & 1,499 & $3 \%$ \\
\hline & 기타 & 25,028 & $53 \%$ & & 기타 & 12,803 & $27 \%$ \\
\hline
\end{tabular}

(OECD, 2011)

2007년부터 2009년까지 3년간 공여국들의 아프리카 지원 현황을 보면, 지원액으로 10 위권에 든 미국, 프랑스, 영국, 독일, 일본, 네덜란드 등이 총 지원액의 $87 \%$ 를 차지했으며, 특히 아일랜드 (81\%), 벨기에(74\%), 포르투갈(66\%), 덴마크(63\%), 프랑스(63\%) 등은 자국의 총 지원액 중 아프리 카 지역에 지원한 비중이 높은 국가이다. ${ }^{4)}$

〈표 3〉 지원액 및 지원비중으로 본 DAC의 대 아프리카 지원 현황 (2007 2009년 평균)

(USD million, net bilateral disbursements)

\begin{tabular}{c|c|c|c|c|c|c|c}
\hline \multicolumn{3}{c}{ 지원액 기준 } & \multicolumn{4}{c}{ 지원비중 기준 } \\
\hline \multirow{2}{*}{ 순위 } & 국가명 & 3년 평균액 & $\begin{array}{c}\text { DAC에서의 } \\
\text { 총 지원율 }\end{array}$ & 순위 & 국가명 & 3년 평균액 & $\begin{array}{c}\text { 아프리카 } \\
\text { 지원비중 }\end{array}$ \\
\hline 1 & 미국 & 6,635 & $25 \%$ & 1 & 아일랜드 & 526 & $81 \%$ \\
\hline 2 & 프랑스 & 3,673 & $14 \%$ & 2 & 벨기에 & 698 & $74 \%$ \\
\hline 3 & 영국 & 2,617 & $10 \%$ & 3 & 포르투갈 & 186 & $66 \%$ \\
\hline 4 & 독일 & 2,401 & $9 \%$ & 4 & 덴마크 & 898 & $63 \%$ \\
\hline
\end{tabular}

4) OECD (2011)

5) 10 개 공여국 및 기타 지원액의 지원비율을 더하면 $102 \%$ 가 되나, 이는 각 공여국들의 지원비중을 환산하는 과정에서 


\begin{tabular}{c|c|r|r|r|r|r|r}
\hline \multicolumn{5}{c}{ 지원액 기준 } & \multicolumn{4}{c}{ 지원비중 기준 } \\
\hline 순위 & 국가명 & 3년 평균액 & $\begin{array}{c}\text { DAC에서의 } \\
\text { 총 지원율 }\end{array}$ & 순위 & 국가명 & 3년 평균액 & $\begin{array}{r}\text { 아프리카 } \\
\text { 지원비중 }\end{array}$ \\
\hline 5 & 일본 & 1,612 & $6 \%$ & 5 & 프랑스 & 3,673 & $63 \%$ \\
\hline 6 & 네덜란드 & 1,470 & $6 \%$ & 6 & 네덜란드 & 1,470 & $61 \%$ \\
\hline 7 & 캐나다 & 1,295 & $5 \%$ & 7 & 룩셈부르크 & 134 & $56 \%$ \\
\hline 8 & 스페인 & 1,151 & $4 \%$ & 8 & 영국 & 2,617 & $54 \%$ \\
\hline 9 & 스웨덴 & 980 & $4 \%$ & 9 & 핀란드 & 267 & $53 \%$ \\
\hline 10 & 노르웨이 & 949 & $4 \%$ & 10 & 스웨덴 & 980 & $53 \%$ \\
\hline & 기타 & 3,907 & $15 \%$ & & 기타 & 15,239 & $35 \%$ \\
\hline & DAC 총액 & 26,690 & $100 \% 5)$ & & DAC 총액 & 26,690 & $43 \%$ \\
\hline
\end{tabular}

(OECD, 2011)

\section{III. 한국의 뵝아프리카 지원 현황}

한국의 대 아프리카 지원은 한국의 대 아프리카 외교 역사와 그 맥을 함께 한다. 따라서 한국의 대 아프리카 원조 정책은 전체적인 외교 정책의 맥락에서 이해할 수 있다. 결론적으로, 한국은 2006년 '아프리카 개발을 위한 한국의 이니셔티브'의 발표 전까지 아프리카 지역에 대해 크게 관심을 가지지 않아 왔다. 즉, 한국은 최근에 들어서야 아프리카 지역에 관심을 보이며 본격적으로 지원을 실시했다 고 할 수 있다.

한국은 1961년부터 아프리카의 카메룬, 차드, 코트디부아르, 니제르, 베냉, 등 5 개국과 수교를 맺 으면서 아프리카 지역과 본격적인 관계를 맺기 시작했다. ${ }^{6)}$ 그러나 이 당시 한국의 대 아프리카 외교 정책의 특징은 한 마디로 북한과의 이념경쟁으로 인한 국제사회에서의 입지 확보를 위한 노력이었다 고 볼 수 있다. 즉, 한국은 UN을 통해 한반도의 통일과 남북한 문제를 해결하고자했고, 따라서 UN 에 상정되는 한반도 관련 의안의 표 대결에 있어 유리한 입지를 확보하기 위해 UN 회원국으로서 다 수를 차지하고 있는 아프리카 국가들에 대한 외교를 적극적으로 추진했던 것이다. ${ }^{7)}$

그러나 1976년 UN 제 31차 총회부터는 한국문제의 상정이 중지되어 북한과의 이념경쟁을 위한 대 아프리카 외교는 변화하기 시작하였고, 1980 년대부터는 2 차 오일쇼크에 따른 경제적 위기의식과 냉전의 재발을 방지하기 위해 한국의 대 아프리카 외교가 본격화되었다. ${ }^{8)}$

소수점 이하 지원액이 반올림값으로 처리되었기 때문인 것으로 보인다.

6) 외교부 홈페이지. http://www.mofat.go.kr/world/main/index.jsp\#

7) 이호영 (1999), 심의섭 · 박제경 (1989) 
1990년대부터는 본격적으로 북방 대륙 세력과의 화해무드가 조성되었고, 동남아시아의 성장 및 중 국·(구)소련 - 동유럽 등 북방 신시장 개척이 활발해지면서 한국의 아프리카에 대한 관심은 거의 사라 졌다. 그 결과, 한국은 1989년 1990년 사이에 부르키나파소, 니제르, 중앙아프리카공화국, 르완다 등 4 개 공관을 폐쇄했고, 1992 년 모리셔스, 말라위, 시에라리온, 라이베리아, 소말리아 등 5 개 공관 또한 폐쇄하게 되면서, 아프리카는 한국의 외교에서 그 중요성을 상실한 듯 보이기 시작한다. ${ }^{9}$

2006년에 한국의 대 아프리카 외교와 원조정책은 중요한 전환점을 맞게 된다. 한국 정상으로서는 24년 만에 처음으로 노무현 대통령이 아프리카 3국(나이지리아, 알제리, 이집트)을 순방하면서, 2006년 3월 '아프리카 개발을 위한 한국의 이니셔티브'를 발표했다. 이는 향후 3년간 개발 원조에서 부터 통상- 투자 확대 계획 등 종합적인 한국의 대 아프리카 협력 방안을 천명한 한국 정부의 공식 문 서이다. ${ }^{10)}$

이니셔티브의 주요 내용은 첫째, 아프리카 지원 $\mathrm{ODA}$ 를 3 년간 1 억 달러로 증액하는 등 3 배 확대하 고, 둘째, 농어촌개발·행정제도·보건의료·교육·정보통신의 5 개 분야를 중점적으로 지원하고, 프로 젝트나 연수생 1 천명 초청, 봉사단 파견 인원 확대 등의 양자사업과 다자사업을 적절히 병행하는 것 을 골자로 한다. 이니셔티브 후속으로 '제 1차 한국-아프리카 포럼'도 개최하였다. 이 포럼은 한국과 개별 아프리카 국가들과의 양자 관계뿐만 아니라, 한국과 아프리카 대륙 전체의 관계를 강화하는 방 향으로 진행되었다. ${ }^{11)}$

이렇게 한국의 대 아프리카 외교가 2006년부터 본격화된 이유는, 세계 10 위권이라는 경제규모에 합당한 국제사회의 일원으로서의 역할에 부합하려는 것인 동시에, 그 동안 아시아에 집중되어 있었던 대외원조를 다변화하는데 그 목적이 있었다.

〈표 4〉아프리카 이니셔티브의 주요 내용

\begin{tabular}{l|l}
\hline \multicolumn{1}{c|}{ 항 목 } & \multicolumn{1}{c}{ 주요 내용 } \\
\hline 2008년까지 & ○ 무상원조 예산 획기적 증대 \\
대아프리카 ODA 3배 확대 & ○ 확대 예산은 선정(good governance) 국가에 집중 지원 \\
\hline 한국의 개발 경험을 & $\bigcirc$ 향후 3년 내 아프리카인 1,000명을 한국에 초청 \\
아프리카 국가들과 공유 & $\bigcirc$ 봉사단 파견인력을 확대해 지역개발 활동 전개 \\
\hline 아프리카 아동사망률 감소 및 & $\bigcirc$ 의료단 파견 확대 \\
질병퇴치 지원 & ○ 병원 건립, 의료장비 및 백신 개발 지원 \\
\hline
\end{tabular}

8) 강선주 (2008)

9) 이호영 (1999)

10) 아프리카 개발을 위한 한국의 이니셔티브에 관한 자세한 논의 배경, 내용, 평가를 보려면 KOICA (2009). <아 프리카 개발을 위한 한국의 이니셔티브 이행 평가연구 보고서>를 참고할 것.

11) 강선주 (2008) 


\begin{tabular}{|c|c|}
\hline 항 목 & 주요 내용 \\
\hline $\begin{array}{l}\text { 아프리카 기초교육, } \\
\text { 직업교육 지원을 통한 인적 개발 }\end{array}$ & $\begin{array}{l}\text { 학교건립과 교육정보화 지원 } \\
\text { 직업훈련센터 건립, 관련분야 교사 초청 연수 }\end{array}$ \\
\hline $\begin{array}{l}\text { 아프리카의 식량문제 해결과 } \\
\text { 1차 산업 육성 지원 }\end{array}$ & $\begin{array}{l}\text { ○ 농업기술 전수 및 농촌 인프라 구축 지원 } \\
\text { 어업 및 수산 양식 분야 기술 지원 }\end{array}$ \\
\hline $\begin{array}{l}\text { 한국의 첨단 IT 기술 공유로 } \\
\text { 정보화 격차해소 }\end{array}$ & $\begin{array}{l}\text { OIT 분야 연수생 초청, 봉사단 파견확대 } \\
\text { OIT 훈련원 건립, 전자정부 사업 지원 }\end{array}$ \\
\hline $\begin{array}{l}\text { 다양한 분야의 } \\
\text { 한국·아프리카 개발 효율성 증진 }\end{array}$ & $\begin{array}{l}\text { 민·관·학 협의체인 한·아프리카 포럼, } \\
\text { 한국·아프리카 경제협력 포럼 활성화 }\end{array}$ \\
\hline $\begin{array}{l}\text { 국제기구와 협력해 } \\
\text { 아프리카 개발 효율성 증진 }\end{array}$ & $\begin{array}{l}\text { O 세계식량계획(WFP), 유엔공업개발기구(UNIDO), } \\
\text { 세계관광기구(WTO)와 협력사업 추진 }\end{array}$ \\
\hline $\begin{array}{l}\text { 아프리카의 무역 역량 배양 및 } \\
\text { 통상·투자 확대 }\end{array}$ & $\begin{array}{l}\mathrm{O} \text { 최빈국에 대한 무관세, 무쿼터 수입 품목 확대 } \\
\bigcirc \text { 통상 투자사절단 파견 등 기업인 간 교류 확대 }\end{array}$ \\
\hline $\begin{array}{l}\text { 아프리카 주인의식 제고와 } \\
\text { 아프리카 협력사업 추진 }\end{array}$ & $\begin{array}{l}\mathrm{O} \text { 아프리카연합(AU)의 아프리카 개발을 위한 신파트너십(NEPAD)과 } \\
\text { 자주적 노력 지원 위한 협력사업 실시 }\end{array}$ \\
\hline
\end{tabular}

(외교통상부, 2007; 황규득, 2009에서 재인용)

이렇게 2006년부터 아프리카 원조가 본격화되면서부터 한국은 아프리카 지원규모를 증대하기 시 작하여, 2008년에는 약 1 억 달러를 지원(양자원조)함으로써 2005년 대비 약 2.5배 확대하는 성과를 달성했다.

\section{〈표 5〉한국의 대 아프리카 지원 총액}

(순지출, 백만달러)

\begin{tabular}{c|c|c|c|c}
\hline 구분 & 2005년 & 2006년 & 2007년 & 2008년 \\
\hline 무상원조 & 17.8 & 26.1 & 51.9 & 73.53 \\
\hline 유상원조 & 21.3 & 21.7 & 18.3 & 30.55 \\
\hline 합계 & 39.1 & 47.8 & 70.2 & 104.08 \\
(비중: \%) & $(8.4 \%)$ & $(12.7 \%)$ & $(14.4 \%)$ & $(19.3 \%)$ \\
\hline
\end{tabular}

(한국수출입은행, 2005, 2006, 2007, 2008)

이후 2009년 11월 24일『제2차 한-아프리카 포럼 서울선언』과 함께『한-아프리카 개발협력 기 본구상 2009-2012』를 채택함으로써, 한국은 대 아프리카 지원 내용을 보다 구체화한 계기를 마련하 였다. 이 문서에서는 대 아프리카 ODA를 2012년까지 2008년 대비 배로 증액하고, 2009년 2012년 간 아프리카인 연수생 초청을 5 천명까지 확대하며, 아프리카 협력국가에 대해 해외봉사단("World Friends Korea”) 파견을 1천명 이상으로 확대한다는 것을 주요 내용으로 담고 있다. ${ }^{12)}$ 
〈표 6〉제2차 한-아프리카 포럼 서울선언 2009 주요 내용

\begin{tabular}{|c|c|}
\hline 항목 & 주요 내용 \\
\hline 전문 & $\begin{array}{l}\text { O 2009.6월 AU 각료이사회의 한-아프리카 포럼 지지 결정 상기 } \\
\text { O 2006.11월 제1차 한-아프리카 포럼이 상호간 파트너십 발전을 위한 협력의 틀 마련 } \\
\text { O 아프리카 연합 헌장의 채택(2002), 개발, 평화 및 안보 사안에서 아프리카 연합의 역 } \\
\text { 할 증대 등 아프리카의 긍정적 변화 평가 }\end{array}$ \\
\hline 파트너십의 원칙 & $\begin{array}{l}\mathrm{O} \cup N \text { 헌장, 국제법 및 민주주의 존중 } \\
\text { O 상호 이익을 위한 국민들간의 연대, 이해 및 상호 존중 }\end{array}$ \\
\hline UN개혁 & ○ 국제연합의 투명성, 효율성, 책임성 제고를 위해 개혁 지속 필요성 \\
\hline 군축 및 테러방지 & $\begin{array}{l}\text { O 테러리즘, 해적활동, 대량살상무기, 소형무기의 불법거래, 인권 } \\
\text { 침해에 대응하는 국제사회의 노력 지지 }\end{array}$ \\
\hline G20 정상회의 & $\begin{array}{l}\text { O 한국의 G20 정상회의 의장국 수임 환영, G20가 빈곤감소와 개발 협력에 기대하는 } \\
\text { 국제경제협력의 중요한 논의의 장으로서 역할을 강화할 것을 기대 }\end{array}$ \\
\hline $\begin{array}{l}\text { 기후변화정상회의 } \\
\text { 및 녹색성장 }\end{array}$ & $\begin{array}{l}\text { O 2009.12월 코펜하겐 정상회의에서 기후변화와 환경파괴, 에너지 안보에 대한 우려를 } \\
\text { 전달, 저탄소 녹색성장 패러다임에 근거한 지속가능한 발전 필요성 강조 }\end{array}$ \\
\hline MDGs 달성 노력 & O 국제금융위기 속에서 MDGs 달성을 위한 국제사회의 지속적 개발 협력 촉구 \\
\hline 대아프리카 ODA & O 2012년까지 한국의 대아프리카 ODA를 2008년 대비 2배 증액 공약 환영 \\
\hline 주요 협력 분야 & $\begin{array}{l}O \text { 식량위기 대처 } \\
\bigcirc \text { 기후변화 대처 및 녹색성장 지원 } \\
\bigcirc \text { 인적역량 강화 및 거버넌스 증진 } \\
\bigcirc \mathrm{MDGS} \text { 목표 달성을 위한 핵심 분야 } \\
\quad \text { 교육, 공중보건, 의료서비스 및 농업 }\end{array}$ \\
\hline 교육 및 투자 확대 & $\begin{array}{l}\text { ○ 친기업적 환경 조성, 무역사절단 교류, 비즈니스 포럼 개최 등 교류 장려 } \\
\bigcirc \text { 철도, 항만, 도로, 지원분야 협력 확대 }\end{array}$ \\
\hline 식량안보 협력 & $\begin{array}{l}\mathrm{O} \text { 물의 사회·경제·환경적 기능 중요성 인식, 깨끗하고 안전한 물에 대한 접근권 증 } \\
\text { 진 및 농업·산업적 목적으로 지속가능한 사용 강조 } \\
\text { 식량 생산 증진을 위한 농업개발 분야 협력사업 및 프로그램 발굴 }\end{array}$ \\
\hline 차기 포럼 개최 & ○ 차기 포럼 2012년 개최 \\
\hline
\end{tabular}

(외교통상부, 2009)

12) 보다 자세한 내용은 '제2차 한-아프리카 포럼 서울선언(2009년) 결과 문서'를 참고할 것. 
〈표 7〉 한-아프리카 개발협력 기본구상 2009 2012 주요 내용

\begin{tabular}{|c|c|}
\hline 항목 & 주요 내용 \\
\hline 전문 & $\begin{array}{l}\text { O 아프리카의 빈곤퇴치 및 지속가능한 발전 달성 지원 및 대한민국과 아프리카 국가 } \\
\text { 상호번영 증진 } \\
\text { 이를 위해 2012년까지 한국의 대아프리카 공적개발원조 (2008년 대비) 2배 확대 및 } \\
\text { 파트너십의 효과 제고 }\end{array}$ \\
\hline $\begin{array}{l}\text { 빈곤퇴치 및 } \\
\text { 지속가능한 발전 }\end{array}$ & $\begin{array}{l}\text { O 아프리카 국가의 국가개발전략 수립 지원 및 전문가 파견 확대 } \\
\text { O 2009 2012년간 아프리카인 연수생 5천명 초청 및 해외봉사단 1천명 파견 }\end{array}$ \\
\hline 농업 및 농촌개발 & $\begin{array}{l}\text { O 농업인프라 구축 및 농업기술 현대화, 농업생산성 향상을 통한 농촌 소득증가 지원 } \\
\text { O 포괄적 아프리카 농업개발프로그램(CAADP) 등 아프리카 주도의 프로그램에 협력하면 } \\
\text { 서, 국가 주도의 통합적, 지속가능한 프로그램 수립 및 이행 지원 } \\
\text { 식량위기 해결을 위한 협력과 쌀 생산 모범사례 공유 및 기술원조 증진 }\end{array}$ \\
\hline 교육 및 직업훈련 & $\begin{array}{l}\bigcirc \text { 교육시설, 제도 및 교과과정 개발 지원 } \\
\text { ○ 정부 초청 장학금 사업(Scholarship programmes) 확대 } \\
\text { 직업훈련센터 설립 및 직업훈련 프로그램 구축 }\end{array}$ \\
\hline 공중 보건서비스 & $\begin{array}{l}\mathrm{O} \text { 기초보건 및 의료서비스 개선을 위해 의료시설, 장비 등 제공 } \\
\text { O 모성, 아동보건 포함 가족계획 및 보건 교육프로그램 정책 수립 지원 } \\
\text { ○ 말라리아, 결핵, HIV/ADS 등 질병확산 방지를 위한 역량강화 지원 }\end{array}$ \\
\hline 무역 및 투자 & $\begin{array}{l}\bigcirc \text { 수출역량 구축을 위해 인프라 및 제도 개선 지원 } \\
\text { 아프리카 최빈국에 대한 무관세, 무쿼터 수입품목 확대 } \\
\bigcirc \text { 외국인 투자 유치 및 기술전수를 위한 조치 마련 }\end{array}$ \\
\hline $\begin{array}{l}\text { 정보통신기술 } \\
\text { (ICT) }\end{array}$ & $\begin{array}{l}\text { O ICT 인프라 구축 및 기술전수 확대 } \\
\text { O ICT 훈련센터 구축 및 전자정부 프로젝트 지원 }\end{array}$ \\
\hline 환경 및 기후변화 & $\begin{array}{l}\text { ○ 지속가능한 환경 유지를 위한 계획 수립, 인프라 구축, 기술원조 확대 } \\
\text { ○ 재생가능한 에너지와 청정에너지자원 개발 및 사용 역량 강화 }\end{array}$ \\
\hline $\begin{array}{l}\text { 지역기구 및 } \\
\text { 국제기구와의 협력 }\end{array}$ & $\begin{array}{l}\text { O 개발협력을 위한 국제연합 및 국제금융시스템 개혁에 협력 } \\
O \text { WFP, UNDP, UNICEF, 세계은행, 아프리카개발은행(AfDB) 등의 국제기구와 지속 협력 } \\
O \text { 아프리카 지역경제공동체(RECS) 및 아프리카 개발을 위한 새로운 파트너십(NEPAD)과 } \\
\text { 협력 확대 }\end{array}$ \\
\hline $\begin{array}{l}\text { 민간부문 및 } \\
\text { 시민사회와의 협력 }\end{array}$ & O 민관파트너십(public-private partnership) 활성화 및 NGO 및 학계와의 협력 강화 \\
\hline 파트너십 효과 제고 & $\begin{array}{l}\text { ○ 한-아 포럼 등 협력체제와 양자간 정책대화 등 지속적인 대화 추진 } \\
\text { 아프리카 국가들의 국가개발계획 및 빈곤감소 전략에 일치하도록 개발협력 체제 구축 } \\
\text { 최빈국 및 고채무빈국(HIPCS) 중심으로 비구속성원조 지속 확대 }\end{array}$ \\
\hline
\end{tabular}

(외교통상부, 2009) 
그러나 현재 한국의 대 아프리카 지원 확대에 관한 중대한 문제는 2009 년 『제2차 한-아프리카 포 럼 서울선언』과 함께 채택된한-아프리카 개발협력 기본구상 2009-2012』이후에 구체적인 이행계 획(action plan)이 마련되지 않았다는 것이다. 즉, 『한-아프리카 개발협력 기본구상 2009-2012』는 농업 및 농촌개발, 교육 및 직업훈련, 공중 보건, 무역 및 투자, 정보통신기술(ICT), 환경 및 기후변 화, 지역기구 및 국제기구와의 협력, 민간부문 및 시민사회와의 협력, 파트너십 효과 제고 등 다양한 분야에 걸쳐 핵심적 지원 공약을 담고는 있지만, 이 지원 내용을 이행하기 위한 구체적인 계획과 목 표가 없기 때문에 사실상 일관된 전략 하에 체계적인 지원이 어렵고, 이 공약들의 이행정도를 평가하 는 것 역시 어려운 상황이라 하겠다.

한국은 원조체계의 분절화 정도가 심하고 수원국의 요청 및 현지의 사업발굴에 따른 개별적 방식 으로 지원을 실시하고 있다. 이러한 상황에서 한-아프리카 개발협력 기본구상 2009-2012』와 같이 구체적인 실행계획이 부재한 아프리카 지원전략은 곧 추상적인 상태로 머물러 있을 가능성이 크다는 것을 시사한다. 또한, 시행체계가 분리되어 있는 한국 원조의 상황에서 통합적이고도 유기적인 아프 리카 지원전략의 도출이 가능한가에 대해서도 의문이 드는 것이 사실이다.

다음 장에서는 이러한 한계점들을 고려하여 무상원조를 중심으로 한 한국의 대 아프리카 지원전략 에 대한 몇 가지 제안을 하고자 한다.

\section{IV. 무상원조의 對아프리카 지원전략 제안}

앞서 언급했듯이, 한국은 현재 유무상 원조체계 및 무상원조 내 원조 또한 다양한 정부부처의 시 행으로 분절화 되어 있고, 최근에서야 총리실의 주도로 이러한 분절화 현상에 의한 다양한 문제들을 해결하고자 시도하고 있다. ${ }^{13)}$ 따라서 현 시점에서는 총리실을 중심으로 지역전략 수립이 추진되지 않 는 한, 각기 시행체계가 상이한 유무상 원조를 아우르는 통합적 대 아프리카 지원전략을 수립하기가 쉽지 않은 상황이다.

또한, 근본적으로 한국은 아프리카 외교 및 원조 역사가 짧아 아프리카의 정치 · 경제 · 사회 · 문화 - 역사 등에 대한 체계적인 이해와 정보를 축적하지 못했고, 이러한 지역전략 수립에 필수적인 지역이 해에 대한 결핍은 체계적 - 구체적인 전략을 수립하는데 중대한 한계로 작용하는 것이 사실이다.

이렇게 한국이 아프리카 지역전략을 수립하는데 따른 한계들을 고려하여, 본 장에서는 $\mathrm{KOICA}$ 를 중심으로 무상원조의 대 아프리카 지원전략을 고찰하고, 장기적인 관점에서 아프리카 지원전략이 본 제안을 기반으로 구체화될 수 있는 기회를 제공하고자 한다.

13) 대표적인 예로, 한국은 2011년부터 유· 무상 통합으로 중점협력국가를 선정하였고, 이 국가들에 유·무상 통합 CPS 를 수립하고 있다. 현재 아프리카 지역에서는 가나가 첫 CPS 수립 대상국으로, CPS 수립 중에 있다. 


\section{1. 지원거점국가 지정 및 집중지원}

한국은 2010년에 국제개발협력위원회에서 유·무상 통합으로 26개 중점협력국가(안)를 선정하였 고, 이 중 아프리카지역 중점협력국은 8개국이다. 또한, KOICA는 2011년부터 지역체제로 전환하면 서 아프리카부 하에 동아프리카팀 및 서아프리카팀을 두었다. ${ }^{14)}$

먼저, 변화된 $\mathrm{KOICA}$ 의 지역체제를 기초로 아프리카 대륙을 (남)동쪽과 (북)서쪽으로 이분화 하여, 각 지역에서 중점협력국으로 선정된 국가 중 1 2개국을 지역 거점 국가로 지정 - 집중 지원하는 전략 을 제안한다.

한국은 최근에서야 대 아프리카 원조 규모를 확대하고 있기 때문에, 한국의 입장에서나 협력대상국 의 입장에서 양적 - 질적으로 모두가 만족할만한 지원을 하기 어려운 상황이다. 따라서 한국이 아프리 카를 지원할 때 가장 우선적으로 고민해야할 것이 바로 우리의 원조를 '어느 지역 내 어떤 국가'를 중 심으로 점진적으로 확대할 것인가를 결정하는 일일 것이다. 이러한 방식은 장기적인 관점에서도 향후 한국이 대 아프리카 지원을 확대할 때 체계적인 로드맵을 그려나갈 수 있다는 점에서 유용하다.

특히, 어느 지역이나 동일하겠으나 아프리카는 국가마다 그 특성이 매우 뚜렷하여 아프리카 대륙 전체의 일관된 특성을 찾기가 어렵고, ${ }^{15)}$ 총 53 개국으로 구성된 아프리카에 개별국가들을 중심으로 접근하는 것 역시 다소 효과성이 떨어진다. 따라서 아프리카 대륙의 지역 및 권역을 중심으로 지원하 거나, 그 지역에 형성된 기구(공동체)를 중심으로 지원하는 방법은 효과적인 아프리카 지역 접근법으 로도 충분히 고려해 볼 만하다.

대표적으로 네덜란드는 아프리카 대륙의 지역별 거점국가를 선정하여 그 국가들을 중심으로 지원 하고 있다. 네덜란드는 아프리카 협력국을 크게 동 - 서 · 남 · 북부 지역으로 구분하고, 각 지역마다 거점국가를 선정하여 중점 지원하는 정책을 실시하고 있다.

〈표 8〉네덜란드의 지역별 아프리카 협력국

\begin{tabular}{c|c|c|c}
\hline 북부 (1) & 서부 (6) & 동부 (5) & 남부 (3) \\
\hline \multirow{2}{*}{ 이집트 } & 말리, 세네갈, 가나, & 에리트리아, 우간다, & 잠비아, 모잠비크, \\
& 카페베르데, 베냉, & 에티오피아, 케냐, & 남아프리카공화국 \\
& 부르키나 파소 & 탄자니아 & \\
\hline
\end{tabular}

(네덜란드 외교부 홈페이지, 검색일: 2010.6.18)

14) $\mathrm{KOICA}$ 의 지역부서는 크게 아시아 1 부(동남아시아 $1 \cdot 2$ 팀), 아시아2부(서남아시아팀, 중앙아시아· CIS팀), 아프리카부 (동아프리카팀, 서아프리카팀), 중동 · 중남미부(중남미팀, 중동 · 아프간팀)로 구분된다.

15) 일례로 MDGs 이행현황만 보더라도, 아프리카 대륙의 전반적인 MDGs 달성가능성은 부정적으로 평가되고 있지만, 가 나, 에티오피아, 말라위 등의 국가들은 2015년까지 전반적인 MDGs 목표들을 모두 달성할 것으로 기대되는 등, 각 국 가마다 상황이 상이하다. 
아프리카 동부지역의 Horn of Africa 지역에서는 분쟁으로 인한 식량부족, HIV/AIDS, 난민, 인 프라 부족 등이 주된 문제인데, 이는 지역적인 차원에서 해결되어야할 문제인 만큼 Horn of Africa 는 특화된 지원전략이 필요한 지역이다. 이에 네덜란드는 에티오피아를 Horn of Africa의 거점국가 로 지정하여 집중적으로 지원하고 있다. 서부지역 거점국가는 세네갈이며, 세네갈은 서부지역에서도 상대적으로 안정적인 국가로서 지역 평화와 안보의 중요한 중재자 역할을 담당한다. 협력국 중 잠비 아는 남부지역의 거점국가로, 앙골라와 콩고민주공화국 등 분쟁 국가들을 중재하고, 그 국가들에서 발생한 난민들을 수용하는 등 지역 내 평화와 안정을 도모하는 역할을 담당하고 있다.

실제로 네덜란드가 '지역 거점국가'를 어떻게 지원하고 있는지는 공개되어 있지 않아, 이러한 지역 거점국가의 실체를 정확히 파악하기 어려운 것이 사실이다. 그러나 아프리카 지역 전략을 논할 때 거 점국가의 존재는 네덜란드의 대 아프리카 지원 전략이 구체적이며 체계적이라는 인상을 주고, 소수 중점협력국을 '선택과 집중'의 원칙하에 지원하고 있다는 사실을 잘 보여주는 예라고 하겠다.

또한, 네덜란드는 여러 지역 중에서도 특히 Horn of Africa의 분쟁지역을 자국의 특별 지원지역으 로 지정하여 분쟁 - 취약국에 대한 지원을 특화하고 있다는 점도 주목할 만하다. 이 지역에 대한 네덜 란드의 높은 관심은 네덜란드 외교부의 아프리카 분과의 구성에서 잘 나타난다. 아프리카 분과는 크 게 사하라이남 및 북아프리카 - 중동지역으로 이분화되고, 그 중 사하라이남 아프리카 분과는 다시 동 부, 서부, Horn of Africa, 중앙, 남부지역으로 나누어져있다. 이처럼 한국이 장기적인 관점에서 특 정 문제 지역에 대한 충분한 이해와 체계적인 전략을 통해 지속적으로 지원한다면, 한국의 아프리카 지역에 대한 지원을 특화할 수 있을 것이다.

\section{2. 지역기구 지원}

다음으로, 아프리카 지역기구들을 지원하는 방법을 제안한다. 아프리카 지역 내에는 많은 지역기구 들이 있고, 각기 그 기능과 영향력 정도는 상이하나 대체로 유사한 특징을 가진 권역별로 지역기구가 형성되어 있다. 따라서 만일 한국이 특별히 서부지역의 풍부한 인적자원을 기반으로 한 경제성장부문 에 지원하고자 한다면, 서아프리카경제공동체(ECOWAS: Economic Community Of West African States)의 주요 제도 및 정책들을 지원하는 방안을 고려해볼 수 있다. 만일 한국이 선정한 아프리카 중점협력국들이 지역별로 다소 불균형하게 분포되어 있을 경우, 이를 보완하는 하나의 방안으로 지역 기구를 지원하는 방법이 활용될 수 있을 것이다. ${ }^{16)}$

대표적으로, 덴마크는 특별히 1997년부터 남부지역을 지원해왔다. 덴마크는 남부지역의 역사적 경 험, 경제적 변화, 문화 양상 등이 유사한 점을 근거로 이 지역의 지원을 특화하였으며, 남아프리카개

16) 예를 들어, 한국의 중점협력대상국이 동부 및 서부지역에 집중되어 있다면, 남부지역에 대한 지원을 보완하는 방안으 로 '남아프리카개발공동체(SADC: Southern African Development Community)'를 특별 지원하는 것이다. 
발공동체(SADC: Southern African Development Community)를 중점 지원하고 있다. 남부지역 의 범위도 $\mathrm{SADC}$ 회원국으로 한정하고 있으며, 평화 - 안보, 민주주의, 지역통합 등 세 개 부문에 중 점 지원한다.

그러나 덴마크의 지역전략은 지역기구를 기술적 - 재정적으로 지원하는 것에서 크게 벗어나지 않으 며, 구체성이 결여되어 있다는 것이 한계로 지적된다. ${ }^{17)}$ 이는 곧 유사한 역사· 문화적 배경을 공유하 고 있다 하더라도, 결국은 상이할 수밖에 없는 국가들을 한 지역적 카테고리로 분류하여 접근하는 것 이 결코 쉽지 않다는 사실을 시사한다.

물론 한국이 아프리카 내 수많은 지역기구 중 어떤 기구를 선정하여 지원할 것인지의 여부와 과연 현재의 역량과 재원으로 지역기구까지 지원할 수 있는 현실적인 여력이 되는가 하는 점은 신중히 검 토되어야 할 것이다. 그럼에도 자생적인 경제· 사회 발전을 위해 설립된 많은 아프리카 지역기구들을 지원하는 방안은 한국이 아프리카를 지원할 때 발생할 수 있는 지역적 불균형을 해소하고, 보다 효과 적인 아프리카 지역에 대한 지원방법으로 검토해볼만 하다. ${ }^{18)}$

〈표 9〉아프리카 내 주요 지역 기구 현황19)

\begin{tabular}{|c|c|c|c|}
\hline 기구명 & 설립연도 & 가입국 & 목적 \\
\hline $\begin{array}{c}\text { 아랍 마그레브 연합 } \\
\text { (AMU: Arab Maghreb Union) }\end{array}$ & 1989년 & 5개국 ${ }^{20)}$ & $\begin{array}{l}\text { 회원국간 재산, 서비스, 인력 및 자본의 자유 } \\
\text { 로운 교류를 증진 }\end{array}$ \\
\hline $\begin{array}{l}\text { 동남아프리카 공동시장 } \\
\text { (COMESA: Common Market for } \\
\text { Eastern and Southern Africa) }\end{array}$ & 1994년 & 21개국 ${ }^{21)}$ & $\begin{array}{l}\text { 동남 아프리카 지역 안보, 질서, 평화 실현 및 } \\
\text { 1983년 이후 무역특혜협정(PTA)을 통해 이후 } \\
\text { 회원국간 상호협력 증진, 경제 통합 }\end{array}$ \\
\hline $\begin{array}{l}\text { 사헬-사하라 국가공동체 } \\
\text { (CEN-SAD: Community of } \\
\text { Sahel-Saharan States) }\end{array}$ & 1998년 & 28개국 22) & 회원국들 간 자유무역 활성화 \\
\hline $\begin{array}{c}\text { 동아프리카 공동체 } \\
\text { (EAC: East African Community) }\end{array}$ & 2001년로 & 5개국 ${ }^{24)}$ & $\begin{array}{l}\text { 재정금융정책의 조화, 국경간 이동 통제 완 } \\
\text { 화, 자본 원활 이동, 역내 기간산업의 개발을 } \\
\text { 통해 경제통합 및 궁극적인 정치통합 달성 }\end{array}$ \\
\hline
\end{tabular}

17) Danida (1997), Danida (2007)

18) 아프리카 내 지역기구를 지원할 때 특별히 각 지역기구의 현황, 문제점, 비전 등을 면밀히 검토하는 신중한 접근이 필 요하다. 현재 아프리카 내 지역기구는 매우 다양하며, 개별 국가가 2개 이상의 기구에 가입해 있는 경우가 많다. 이렇 게 개별 국가가 중복 가입된 기구의 경우, 영국 식민지 권역과 프랑스 식민지 권역의 문화와 시스템 사이에서 각국의 견해차에 의해 빈번히 충돌이 발생하며, 이는 지역기구가 그 목적을 원활하게 수행하지 못하게 되는 주요 장애요인으 로 작용하기도 하기 때문이다. (한승헌, 2010)

19) 아프리카연합(AU: African Union)은 공식적으로 위의 8개의 지역경제공동체(RECs: Regional Economic Communities)를 아프리카 국가들의 대표적인 지역 연합으로 인정하고 있다. 몇몇 아프리카 국가들은 여러 RECs에 가입하고 있고, 따 라서 서로 경쟁하거나 갈등에 놓이는 경우도 있다. ECOWAS와 SADC는 아프리카 지역 통합을 촉진하는데 중요한 역 할을 하고 있다.

20) 알제리, 리비아, 모로코, 튀니지, 모리타니 


\begin{tabular}{c|c|c|l}
\hline 기구명 & 설립연도 & 가입국 & \multicolumn{1}{c}{ 목적 } \\
\hline $\begin{array}{c}\text { 중앙아프리카경제공동체 } \\
\begin{array}{c}\text { (ECCAS: Economic Community of } \\
\text { Central African States) }\end{array}\end{array}$ & 1985년 & 11개국25) & 경제협력을 통한 지역 내 조화로운 발전 도모 \\
\hline $\begin{array}{c}\text { 서아프리카 경제공동체 } \\
\text { (ECOWAS: Economic Community } \\
\text { of West African States) }\end{array}$ & 1975년 & 15개국 ${ }^{26)}$ & $\begin{array}{l}\text { 관세동맹 및 공동시장 형성을 통해 경제공동 } \\
\text { 체로 발전. 궁극적으로 다른 지역과의 경제공 } \\
\text { 동체 구축 }\end{array}$ \\
\hline $\begin{array}{c}\text { 동아프리카 정부간 개발기구 } \\
\text { (IGAD: Intergovernmental Authority } \\
\text { for Development) }\end{array}$ & 1986년 & 7개국27) & $\begin{array}{l}\text { 식량안보, 환경보호, 평화 및 안보 증진, 경제 } \\
\text { 협력과 통합 }\end{array}$ \\
\hline $\begin{array}{c}\text { 남아프리카 개발공동체 } \\
\text { (SADC: Southern African } \\
\text { Development Community) }\end{array}$ & 1992년 & 15개국28) & $\begin{array}{l}\text { 역내 관세 및 비관세 장벽의 점진적 철폐, 자 } \\
\text { 유무역지대 형성 도모 }\end{array}$ \\
\hline
\end{tabular}

(한승헌, 2010)

\section{3. 개별 협력대상국 내 지역종합개발 추진}

한국은 2008년 에티오피아의 아르시존을 '한국형 농촌개발모델'을 구축할 지역으로 선정하고, ${ }^{29)}$ 현재까지 집중적으로 4 개의 프로젝트 사업과 봉사단원 파견을 실시하고 있다. ${ }^{30)}$ 이는 아르시 지역에

21) 앙골라, 부룬디, 코모로, 지부티, 이집트, 이디오피아, 케냐, 말라위, 짐바브웨, 모리셔스, 모잠비크, 잠비아, 나미비 아, 르완다, 우간다, 수단, 탄자니아, 스와질랜드, 콩고민주공화국, 마다가스카르, 에리트리아 (남아공: 옵저버)

22) 부르키나파소, 차드, 리비아, 말리, 니제르, 수단, 중앙아프리카공화국, 에리트리아, 지부티, 감비아, 세네갈, 이집트, 모로코, 나이지리아, 소말리아, 튀니지, 베냉, 토고, 코트디브와르, 기니비사우, 라이베리아, 가나, 시에라레온, 코모 로스, 기니, 케냐, 모리타니, 상투메프린시페

23) 동아프리카 공동체는 1967년 탄자니아, 케냐, 우간다 세 나라의 주도로 창설되었으나 3국간 상이한 경제발전 단계에 따른 의견 차이와 각국의 내부적인 문제로 1977년에 해체되었다. 이후 2000년 7월 7일에 다시 설립되었으며, 2004년 3 월에 관세 동맹을 체결했다. 2007년에 르완다, 부룬디가 가입했다.

24) 탄자니아, 케냐, 우간다, 르완다, 부룬디

25) 카메룬, 앙골라, 가봉, 적도 기니, 콩고, 콩고민주공화국, 차드, 르완다, 상투메 프린시페, 중앙아프리카 공화국, 부룬디

26) 베냉, 부르키나파소, 카보페르데, 코트디부아르, 감비아, 가나, 기니비사우, 라이베리아, 말리, 나이지리아, 세네갈, 시에라레온, 토고, 기니, 니제르

27) 지부티, 에티오피아, 케냐, 소말리아, 소말리랜드, 수단, 우간다

28) 앙골라, 콩고민주공화국, 탄자니아, 모잠비크, 남아프리카공화국, 레소토, 스와질란드, 나미비아, 보츠와나, 잠비아, 짐바브웨, 말라위, 마다가스카르, 모리셔스, 세이셸

29) '한국형 개발모델이'라는 용어는 현재 수원국과의 파트너십을 강조하는 국제적인 원조 추세 속에서는 그리 적합한 용 어는 아닌 것으로 판단되며, 아직 명확히 그 의미와 내용이 정립되지 않았다. 향후 '한국형 개발모델'이라는 직접적이 고 일방적으로 비춰질 수 있는 공여국 중심적인 용어 대신, 한국이 지원하는 구체분야를 브랜드화하여 간접적이고도 한국의 차별성이 부각될 수 있도록 용어를 수정해 나가야할 필요는 있어 보인다.

30) 에티오피아 아르시존의 종합개발사례는 2011년 1월 31일 개최된 'KOICA 에티오피아 아르시 가족계획 및 모자보건 증진사업 종료보고회'에서 발표((구)지역조정팀, (현)동아프리카팀 장우찬)된 것으로, 발표자의 동의를 얻어 발표내용 을 인용함을 밝혀둔다. 
다양한 사업을 연계함으로써 지역의 빈곤 및 저발전 문제를 효과적으로 해결할 수 있도록 기획되었으 며, '지역종합개발'의 좋은 사례이다.

\section{〈표 10〉아르시존에 추진 중인 KOICA 사업 현황}

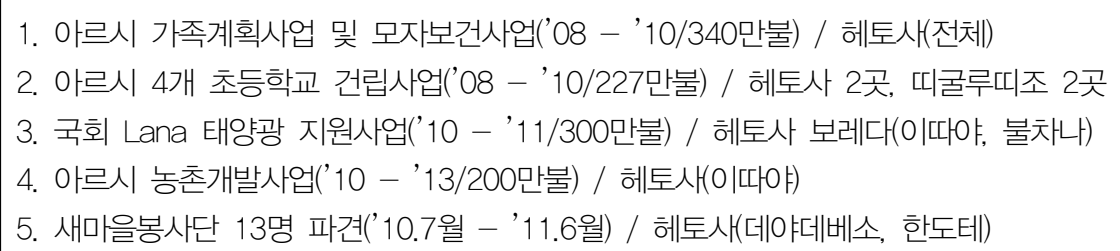

(장우찬, 2011)

아르시존 농촌종합개발사업의 목표는 '주민 생활환경 개선과 인식 변화'이고, 이 목표 하에 '인간다 운 생활을 할 수 있는 기초 환경 조성(1차 목표)'과 '소득증대 및 주민참여 제고(2차 목표)'라는 두 가 지 세부목표를 설정하였다. 목표 달성을 위해 보건과 교육 등 기초 서비스 상황을 개선하고, 궁극적 으로 주민들의 삶의 질을 향상시키기 위한 소득증대사업을 집중적으로 지원하고 있다.

한국은 동 지역의 성과 사례를 에티오피아뿐만 아니라 인근 아프리카 국가에 확대하여 아프리카 개발 모델사례로 적극 활용할 계획이다. 이는 UNECA(UN Economic Council of Africa, 유엔 아프 리카 경제위원회)가 2009년, 2010년 2차례에 걸쳐 한국의 새마을 운동을 아프리카 지역에 확산시키 기 위해 우리 정부의 지원을 요청한 것을 토대로, 향후 국제기구 및 지역기구와의 협력 사업의 수요 가 증대될 수 있다는 점을 감안하여 민-관의 적극적인 파트너십을 통해 지원되었다. ${ }^{31}$

이와 유사한 사례로 탄자니아의 모로고로 지역 농촌종합개발 사업을 들 수 있는데, 이 사업 역시 에티오피아의 아르시존과 같이 농업기반시설 확충, 초등학교 건립, 식수사업 등 종합적으로 지역 개 발을 위해 기획된 프로젝트이다.

한국의 농촌개발경험은 농업개발과 농촌의 지역개발을 별개가 아닌 유기적이고도 통합적으로 고려 하는 '총체적 접근'을 지향하기 때문에 타 원조기관의 접근법과는 차별화된다고 볼 수 있다. 따라서 본 사업들의 내용을 기초로 하여 향후 한국이 타 아프리카 국가들에 대해서도 '지역종합개발'을 통해 개발의 시너지를 높일 수 있도록 전략적인 접근이 필요하다. 비단 농업분야 뿐만 아니라, 궁극적으로 지역 주민들의 총체적인 삶의 질이 개선될 수 있도록 지역마다 상이한 개발 우선과제를 고려하여 지 역종합개발을 계획하고 실행해보는 것이다. 이렇게 지역단위의 종합개발프로그램을 한국의 대 아프 리카 지원전략의 한 축으로 구성하여, 이를 점차 브랜드화하고 발전시키는 방안도 검토해볼 필요가 있다.

31 ) 아르시존 사업은 KOICA뿐만 아니라, 정부(국회, 경상북도, 외교부-KOICA), 대학(연세대, 영남대), 기업(대성), 연구 소(농촌발전연구원)와의 파트너십을 구축하여 진행하고 있다. 


\section{4. 지원 분야 특화 및 브랜드화}

끝으로, 앞의 개별 협력대상국 내 지역종합개발과는 별개로 보건, 농업, 교육, ICT 등 분야별 프로 그램을 '브랜드화'하여 지원하는 방안을 제안한다. 현재 한국은 아프리카 지역에 인프라건설부터 사 회부문, 인적역량개발 등 다양한 분야를 지원하고 있지만, 각 국가마다 공통적으로 지원하는 특정 분 야에 대한 지식축적 및 상호 정보교류 정도가 미미하여 장기적인 관점에서 한국의 대 아프리카 지원 분야의 특화나 차별화를 기대하기 어려운 실정이다.

이러한 동일한 목표 하에 유사한 형태로 지원되는 프로그램을 하나의 명칭으로 통일하여 브랜드화 한다면, 국내뿐만 아니라 아프리카 국가들 및 공여사회에 한국의 지원 분야를 효과적으로 알릴 수 있 고 향후 한국의 대 아프리카 지원 분야 역시 보다 특화시키는 계기를 마련할 수 있을 것이다.

그러나 '특정 분야 프로그램의 브랜드화'를 논하기 이전에 반드시 해결해야할 문제가 있다. 바로 '한국이 아프리카에서 어떤 목적 하에, 어떤 프로그램을 실행하고 있는가'를 제대로 설명할 수 있는 우리의 분명한 전략과 구체 실행계획, 경험적 역량 등이 선행되어야 하는 것이다. 지원 분야의 브랜 드화는 곧 한국이 실행하고 있는 프로그램들을 협력대상국 및 대내외에 효과적으로 홍보하고, 그럼 으로써 협력대상국에서 어떠한 분야에 대한 개발수요가 발생했을 때, 혹은 공여국 간 특정한 분야 에 관해 협업이 논의될 때 한국을 떠올릴 수 있도록 돕는 것이 주된 목적이기 때문이다. 즉, 한국의 지원 목적과 역량이 일관된 전략 하에 체계적으로 정립되지 않는 한 브랜드화를 통한 원조의 시너 지를 기대하기는 사실상 어려운 일이라 하겠다. 그럼에도 지원 분야의 브랜드화를 추진함으로써, 이를 토대로 한국의 대 아프리카 지원 방향과 내용을 구체화해갈 수 있다는 점에서 고려해볼 만하 다 하겠다.

\section{V. 결 어}

지금까지 한국의 대 아프리카 지원 현황을 간단히 설명하고, 몇 가지 지원 전략을 제안해보았다. 여러 차례 언급한 것이지만, 한국은 아프리카 지역에 대한 지역적 이해와 지원 경험이 타 공여국들에 비해 절대적으로 부족하고, 중국과 일본 등 타 국가들의 공격적인 아프리카 지원에 대한 반사적 반응 으로 아프리카에 대한 지원을 확대한 경향이 강하다. 자연히 현재 한국의 대 아프리카 지역전략은 일 관성과 통합성, 구체성이 결여될 수밖에 없었다. 그러나 이미 확대되기 시작한 아프리카 원조를 효과 적으로 이끌어가기 위해서는 구체적이고 치밀한 대 아프리카 지원전략이 반드시 필요한 상황이어서, 아프리카 지원에 관한 한국의 역량과 현실적 필요 사이에는 일정 부분 딜레마가 존재한다.

원론적인 이야기이지만, 우선 한국은 대 아프리카 지원의 목적을 분명히 할 필요가 있다. 여기서 
'지원 목적'은 2010년 제정된 「국제개발협력기본법」 제3조에 제시된 '개도국의 빈곤감소와 삶의 질 향상'이라는 기본정신과 목표에 부합해야 할 것이며, 동시에 향후 이루어지는 모든 대 아프리카 지원 이 이러한 기본정신에 위배되거나 이를 저해하지 않도록 목표와 실행 사이의 일치를 이루는 것이 가 장 중요하다. 이 지원 목적은 곧 최근에서야 아프리카 지원을 확대하는 상황에서 한국이 반드시 제대 로 정비해가야 할 방향성이자, 협력대상국 및 공여국에 우리 원조의 성격을 나타내는 핵심 지표가 될 것이기 때문이다.

한국은 대 아프리카 지원 목적을 명확히 한 이후에, 현재보다 더욱 구체적인 지원 전략 마련에 보 다 역량을 집중해야한다. 2009년 채택된 『한-아프리카 개발협력 기본구상 2009-2012』이후에 구 체적인 실행계획(action plan)이 수립되지 않았다는 사실은, 한국이 대 아프리카 지원에 대한 관심이 체계적이고 실제적인 이행으로 가시화되기 어렵다는 것을 시사한다. 지금까지와 같이 '先 선언, 後 실행'의 관행을 근절하기 위해서라도, 한국은 국제사회에 '한국의 대 아프리카 전략'이라고 소개할 수 있고 우리가 실제로 활용할 수 있는 지역전략 마련에 보다 역량을 집중해야할 것이다. 또한, 유 - 무 상 원조체계가 분절되어 있는 상황에서 한국의 통합적인 대 아프리카 지원 전략이 수립되기 어려운 현실적인 여건을 고려하여, 총리실을 중심으로 통합적 지역 전략 수립이 착수되어야 하겠다. 현재 원 조를 수행하는 각 기관에서 산발적으로 존재하는 아프리카 지역 · 지원 전략이 이제는 한국의 전략으 로 정립되어야할 때이다.

끝으로, 본 글에서 제안한 지원전략은 실제로 한국의 대 아프리카 지원전략이라는 상위 범주와 비 교해봤을 때 하위 전략에 속하며, 그 구체화 수준 역시 향후 지원전략 수립을 위한 아이디어 차원의 제안인 것이 사실이다. 그럼에도 이러한 대 아프리카 지원전략에 대한 다양한 제안들을 바탕으로 한 국의 지원전략이 보다 구체화되는 계기가 마련될 수 있기를 기대한다. 


\section{참고문헌}

\section{1. 국내문헌}

강선주 (2008). 아프리카의 기회와 도전: 한국의 대(對)아프리카 외교 강화 방안 연구. 외교안 보연구원.

심의섭, 박제경 (1989). 한국의 대 아프리카 외교정책 방향. 한국아프리카학회지. 제4집 제 2 호. 외교통상부 (2009). 제2차 한-아프리카 포럼 서울선언(2009년) 결과 문서. 외교통상부.

외교통상부 (2007). 『외교백서』. 외교통상부.

이호영 (1999). 한국의 대 아프리카 외교: 아프리카의 재평가와 발전방향. 한국정치학회보. 제 33집 제3호.

장우찬 (2011). 아프리카 지역종합개발사업 추진 현황 및 방향: 에티오피아 아르시존 사례를 중심으로. $\mathrm{KOICA}$ 에티오피아 아르시 가족계획 및 모자보건 증진사업 종료보고회 발 표자료. 한국국제협력단.

정유아 (2010). “국가지원전략(CAS) 프로세스' 정형화 방안”「KOICA 개발정책포커스」. 제4호. 한국국제협력단.

황규득 (2009). 한국의 대개도국 외교: 과거, 현재, 미래. 한울아카데미.

한국국제협력단 (2009). 아프리카 개발을 위한 한국의 이니셔티브 이행 평가연구 보고서. 한국 국제협력단.

한국수출입은행 (2008). 2008년도 우리나라 ODA통계(확정치)의 주요 내용. 한국수출입은행. 한국수출입은행 (2007). 2008년도 우리나라 ODA통계(확정치)의 주요 내용.한국수출입은행. 한국수출입은행 (2006). 2008년도 우리나라 ODA통계(확정치)의 주요 내용. 한국수출입은행. 한국수출입은행 (2005). 2008년도 우리나라 ODA통계(확정치)의 주요 내용. 한국수출입은행. 한승헌 (2010). “OECD/DAC 회원국의 대 아프리카 지원 전력과 시사점.” ${ }^{\circ} \mathrm{KOICA}$ 개발정책 포커스」. 제5호. 한국국제협력단. 


\section{2. 국외문헌}

Danida (2007). Strategy for Africa: Denmark in Africa a continent on its way. Ministry of Foreign Affairs, Copenhagen, Denmark.

Danida. (1997). Regional strategy for Southern Africa. Ministry of Foreign Affairs, Copenhagen, Denmark.

World Bank (2011). Africa's Future and the World Bank's Support to It(Final Draft).

OECD (2011). DEVELOPMENT AID AT A GLANCE SATISTICS BY REGION - 2. AFRICA. OECD, Paris.

외교통상부. http://www.mofat.go.kr/

한국국제협력단. http://koica.go.kr/

한국수출입은행. http://www.koreaexim.go.kr/kr2/index.jsp

Ministry of Foreign Affairs of Netherlands. http://www.minbuza.nl/en/home 